I wrote to Professor Dresbach a few days after reading this account, and he most kindly sent me a slide, dated January 10, 1903, for examination. Professor Dresbach wrote:

The young man who furnished these peculiar cells was taken ill and left the city, and consequently I never saw him again. I have since learned that he died $* * *$.

It is unfortunate that there is no account of the disease that proved fatal in this case; and it is to be hoped that this defect in the history may be supplied later. It is well known that erythrocytes are often deformedand sometimes many of them are oval-in certain blood diseases. To cite authorities that can be readily consulted, Osler writes, in treating of 'Progressive Pernicious Anemia':

Microscopically the red blood-corpuscles present a great variation in size, and there can be seen large giant forms, megalocytes, which are often ovoid in form, measuring eight, eleven or even fifteen micromillimeters in diameter-a circumstance which Henry regards as indicating a reversion to a lower type. Laache thinks these pathognomonic, and they certainly form a constant feature. ('The Principles and Practice of Medicine,' New York, 1895, p. 729.)

These changes in the form of the corpuscles have been described under the name of poikilocytosis, and are referred to by Flint ('Principles and Practice of Medicine,' Philadelphia, 1886, pp. 60 and 386), in connection with pernicious anemia. Ewing ('Pathology of the Blood,' Philadelphia, 1903, p. 256) writes:

Sometimes in non-infectious purpura hemorrhagica the red corpuscles are undersized and many are oval.

In view of these facts, it seems impossible to accept the proposition that the subject of the observation noted 'was a healthy mulatto.' He certainly was affected with poikilocytosis. As the oval corpuscles in this case measured 10.3 by 4.1 microns-certainly not enlarged, the normal corpuscles being seven to eight microns in diameter-it is possible that the poikilocytosis was a condition antecedent to a severe purpura hemorrhagica, which was the immediate cause of death. In pernicious anemia, the number of corpuscles is diminished and may become as low as 500,000 per cubic millimeter, instead of $5,000,000$, which is the normal average, and megalocytes are nearly always found. Still, as there are no observations-with which I am acquainted, at leastin regard to the blood in pernicious anemia, before grave and distinctive symptoms have appeared, death may have been due to this disease.

Cornell University Medical College, New YoRK, April 25, 1904.

\section{CONVOCATION WEEK.}

The Editor of ScIence writes: "Among the points on which an expression of opinion would be useful are: (1) Should the American Association maintain its sections for special papers or should these be left to the special societies? (2) Should the association attempt to popularize science, and if so how? Should the association include in its scope education, economics, philology, etc.? (4) Should the association meet in summer or winter or both? (5) Should the association meet in regional sections, with only occasional joint meetingș? (6) What should the association do to promote cooperation among men of science and the advancement and diffusion of science?"

After reading the great number of diverse opinions that have appeared in SCIENCE concerning the condition of the American Association and the nature of its work, every subscriber must begin to think something is wrong somewhere, though he may be utterly at a loss to know what remedies to prescribe.

The writer can not help thinking that most that has lately been written on the subject has added to the apparent unrest, on the whole very likely doing more harm than good. Each writer has committed himself to a certain policy, which he thinks should be adopted. With all this talk, it is not difficult to show that large additions of members have been made during the period of special or affiliated societies. Several of these societies have been the means of increasing the membership of the American Association instead of decreasing it. 
1. Let the association keep up all its sections, possibly adding to the number, freely cooperating with special societies, each section showing a willingness to unite in preparing a program with any one or more special societies having a like object.

2. Years ago at meetings of the association, the late W. A. Rogers in Boston and E. S. Morse in Detroit, strenuously advocated the presentation of no papers that did not present the results of original work. Professor Cope often took the same ground, not infrequently helping to reject papers because of their popular nature.

I have recently thought it desirable to have a number of speakers selected by officers of the sections, perhaps with the approval of the council, to present some topic or series of topics in a popular way to attract 'outsiders.' It would hardly be safe to permit any volunteers to present papers on a popular topic.

3. Education, economics, but not philology.

4. Once a year, preferably in winter, till this date has had a fair trial.

5. Meet most of the time in populous regions from Washington to Boston, Detroit, Chicago, where many people are most sure to attend.

6. The association through ScIEnce is now performing a great work. W. J. BEAL.

\section{ERRORS IN NOMENCLATURE.}

To the Editor of Science: In the American Naturalist for February is a paper by Miss E. G. Mitchell purporting to date from Cornell University and expressing acknowledgments to Instructor H. D. Reed and myself. Besides some typographic errors it contains so many incorrect generic and specific names that, in justice to the university and ourselves, Dr. Reed and I feel obliged to disclaim responsibility for them. Two years ago some dissections and observations were made by Miss Mitchell in this laboratory, and she was probably encouraged to complete and publish them. But at that time our concern was with the subject-matter, and we did not undertake to verify the names of the fishes examined. Neither the manuscript nor a proof has been submitted to us recently, as would have been required before assenting to publication as if from the department. Others, like ourselves, probably query why the paper was not passed upon by the ichthyological editor of the Naturalist. A list of corrections has been sent to Miss Mitchell, in Louisiana, with the expectation that she will request their immediate publication. BuRT G. WILDER.

IthaCA, N. Y.

May 2, 1904.

SPECIAL ARTICLES.

A REFERENCE TO THE ORIGIN OF SPECIES IN AN EARLY LETTER (1796) SIGNED BY BOTH LAMARCK AND GEOFFROY.

Among the papers of the elder Peale which were recently dispersed in Philadelphia was a four-page letter in folio, on official paper, signed by Lamarck as director of the Museum of Natural History and by Geoffroy as 'professor and secretary.' The writing is in the hand of Geoffroy, and it is, accordingly, fair to assume the composition and the doing into English were also his. The ideas, however, are subscribed to by Lamarck 'for director' in his characteristic hand.

One might add that manuscripts connected with Lamarck are rare; in fact, few are known which touch upon variation in species, and the present letter may, therefore, be quoted literatim, for what it contains of an extra philosophical nature will be at least of human interest as indicating the type of correspondence which such a man as Peale would have read to his colleagues of the Academy of Natural Sciences.

$$
\begin{gathered}
\text { at Paris, } 30 \text { Juny } \\
\text { LIBERTe, ÉgALITE, Fraternite. } \\
\text { MUSEUM NATIONAL } \\
\text { D'HISTOIRE NATURELLE. }
\end{gathered}
$$

The Professors directors of the National Museum of Natural History To Mr. Peales, at Philadelphita.

Sir,

Mr. Beauvois has transmitted us the letter wich you directed to him, by wich you propose yoursel to enter into a correspondance with the Museum of Natural History of the french Nation. We are pleased to seize an opportunity wich can afford us some communication with a Naturalist of your merit. Every thing you announce is 